\title{
Diet and breed alter community structures of rumen protozoa in cattle subjected to different feeding systems
}

\section{Dieta e raça alteram a estrutura da comunidade de protozoários ruminais em bovinos submetidos a diferentes sistemas de alimentação}

\author{
Cândida Camila dos Reis ${ }^{1 *}$; Emilyn Midori Maeda ${ }^{2}$; Franciane Cedrola ${ }^{3}$; Elias \\ Nunes Martins ${ }^{4}$; Fabiana Matielo De Paula ${ }^{5}$ Isabel Martinele ${ }^{6}$
}

\begin{abstract}
The objective were to identify and quantify the rumen protozoa from two genetic groups of beef cattle (Nellore and crossbred European beef cattle) subjected to three feeding systems (pasture, pasture supplement, and confined). Samples of rumen contents were obtained from the center of the ruminal mass after slaughter. Quantification and identification of rumen protozoa were performed with a Sedgewick-Rafter counting chamber by optic microscopy. Data were analyzed using general linear analysis methodology with a Poisson distribution $(1 \%)$. In addition, the data underwent of Analisys Principal Component. A effect on ruminal protozoa was observed for the diets and breeds analyzed. Was identified 14 genera, among which Entodinium was predominant in all animals analyzed. Ciliates belonging to Entodiniomorphida, Eodinium, Epidinium, Eremoplastron, Eudiplodinium, Metadinium, and Ostracodinium showed highest density in Nellore animals when compared with the crossbreed, Nellore $\times$ European. Larger numbers of protozoa from the family Isotrichidae (Dasytricha and Isotricha) were observed in animals maintained by pasture or pasture supplement feeding. According to the kind of feeding, those fed exclusively with pasture had a greater diversity of ciliates in comparison to those restricted to, or supplemented with pasture. In one animal, the occurrence of ciliates belonging to the genus Buetschlia, was observed (prevalence of $1.66 \%$ ), which is one of only a few records of this genus in ruminants.
\end{abstract}

Key words: Breed. Cattle. Isotrichidae. Ophryoscolecidae. Pasture.

\section{Resumo}

O objetivo do presente estudo foi identificar e quantificar os protozoários do rúmen de dois grupos genéticos de bovinos de corte (Nelore e cruzados Nelore x Europeu) submetidos a três sistemas de

\footnotetext{
1 M.e em Zootecnia, Universidade Tecnológica Federal do Paraná, UTFPR, Programa de Pós-Graduação em Zootecnia, PPGZOO, Dois Vizinhos, PR, Brasil. E-mail: candidareis@zootecnista.com.br

2 Profa, UTFPR, Programa de Pós-Graduação em Zootecnia, PPGZOO, Dois Vizinhos, PR, Brasil. E-mail: maedazoo@yahoo. com.br

3 M.e em Ciência Biológicas, Comportamento e Biologia Animal, Universidade Federal de Juiz de Fora, UFJF, Laboratório de Protozoologia Anima, Pós Graduação em Ciências Biológicas, Comportamento e Biologia Animal, Juiz de Fora, MG, Brasil. E-mail: francedrola@gmail.com

4 Pesquisador Sênior, UTFPR, Dois Vizinhos, PR, Brasil. E-mail: eliasnunesmartins54@gmail.com

5 Pesquisadora, UTFPR, Dois Vizinhos, PR, Brasil. E-mail: fabianadepaula3@hotmail.com

6 Pesquisadora, UFJF, Laboratório de Protozoologia Animal, Pós-Graduação em Ciências Biológicas, Comportamento e Biologia Animal, Juiz de Fora, MG, Brasil. E-mail: isabelmartinele@yahoo.com.br

Author for correspondence
} 
alimentação (pastagem, pastagem com suplementação e confinado). Amostras do conteúdo ruminal foram obtidas do centro da massa ruminal após o abate. A quantificação e identificação dos protozoários do rúmen foram realizadas por meio de câmara de contagem de Sedgewick-Rafter por microscopia óptica. Os dados foram analisados por meio de metodologia de análise linear geral com distribuição de Poisson (1\%). Além disso, os dados foram submetidos à análise de componentes principais. Houve efeito sobre os protozoários ruminais $(\mathrm{P}<0,001)$ para as dietas e raças analisadas. Foram identificados 14 gêneros, dentre os quais, o gênero Entodinium foi predominante em todos os animais analisados. Os ciliados pertencentes a Entodiniomorphida, Eodinium, Epidinium, Eremoplastron, Eudiplodinium, Metadinium e Ostracodinium apresentaram maior densidade em animais Nelore quando comparados com os cruzados Nelore $\times$ Europeu. Um maior número de protozoários da família Isotrichidae (Dasytricha e Isotricha) foi observado em animais mantidos por pastagem ou suplemento alimentar. De acordo com o tipo de alimentação, aqueles alimentados exclusivamente com pasto apresentaram maior diversidade de ciliados em comparação àqueles restritos ou suplementados com pastagem. Em um dos animais do experimento, foi observada a ocorrência de ciliados pertencentes ao gênero Buetschlia (prevalência de 1,66\%), que é um dos poucos registros desse gênero em ruminantes.

Palavras-chave: Raça. Bovino. Isotrichidae. Ophryoscolecidae. Pastagem.

\section{Introduction}

The rumen provides a favorable environment for the establishment and development of populations of bacteria, archaea, fungi, and flagellated and ciliated protozoa. These microorganisms live in mutualistic association with the host and participate in various processes of host physiology (DEHORITY, 1986). Owing to the activities of this ruminal microbiota, the host is able to utilize a wide variety of otherwise indigestible foods as nutrient sources, such as structural carbohydrates (cellulose, hemicellulose, and lignin, among others) (WRIGHT, 2015; NEWBOLD et al., 2015). Rumen ciliates are a morphologically and physiologically diverse group of Microeukaryotes that are divided into two major orders, Entodiniomorphida and Vestibuliferida. Entodiniomorphid ciliates include approximately 20 genera and are characterized as preferably cellulolytic; vestibuliferid ciliates include four genera, and preferably degrade nonstructural carbohydrates (WRIGHT, 2015).

The density and richness (number of genera) of rumen ciliated protozoa are very much influenced by the feeding conditions of the ruminant hosts (WRIGH et al., 2015; CEDROLA et al., 2016). In high forage diets, the density is low, and the richness is high, whereas in diets rich in concentrates, the opposite occurs. According to Martinele et al. (2008), fiber is essential for ruminants, stimulating rumination and saliva production, maintaining a constant rumen $\mathrm{pH}$, and favoring the establishment of ciliated populations. In contrast, diets containing high levels of concentrates are rich in rapidly fermentable carbohydrates, and the fermentation products include volatile fatty acids that decrease the rumen $\mathrm{ph}$. A reduction in rumen $\mathrm{pH}$ has a deleterious effect on many genera of rumen ciliates (CEDROLA et al., 2016).

Among the zebu breeds produced in Brazil, the Nellore breed comprises most herds, and is intended almost exclusively for the production of meat. This breed is characterized by hardiness, adaptability, and resistance to various conditions of pastures and parasites. Taurine cattle are characterized by greater adaptation to low temperatures and high productivity. Crosses between breeds of Indian and European origin have been performed to achieve complementarity of these features and to maximize production in rustic environments (ARTMANN et al., 2014). Besides genetic attributes, other factors contribute to productivity, including the nature of the diet and ruminal fermentation characteristics. The latter is closely related to the ruminal microbiota, as the nature of the volatile fatty acids and the availability of microbial protein to the host 
animal will depend on the profile of this community (CERSOSIMO et al., 2016).

We hypothesized that breed and diet would alter the community structure and density of naturally occurring rumen protozoa in beef cattle herds in Brazil. Our objectives were to identify and quantify the populations of ciliated protozoa in the rumen of Nellore and crossbred European beef cattle subjected to different feeding systems (pasture, pasture supplement, and confined).

\section{Material and Methods}

\section{Animals and treatments}

Samples of rumen contents were obtained from two genetic groups of cattle Nellore $(\mathrm{N}=$ $30)$ and crossbreed European beef cattle $(\mathrm{N}=30)$. The animals were maintained at different farms in the Southwest of Paraná State, Brazil, located in a radius of $50 \mathrm{~km}$, eighth the same conditions edaphoclimatic, from June to September 2014 using three feeding systems: pasture (Nellore: Bermuda grass; Cross bred European beef cattle: Ryegrass); pasture supplement (Nellore: Bermuda grass + supplement; crossbred Nellore x European: Oats and Ryegrass + supplement) and confined (corn silage and corn / soy concentrate for both genetic groups, in the proportion of 70:30 [voluminous: concentrate]). Supplementation was performed with $18 \%$ crude commercial protein, provided at the amount of $2 \%$ of body weight. The climate of the region is mesotermic subtropical humid (CA), according to the Koppen classification, with an average temperature of 18.1 and 16.9 ${ }^{\circ} \mathrm{C}$ (maximum and minimum), and an average precipitation of $194.8 \mathrm{~mm}$, in the months of July to September 2014 (GRUPO DE ESTUDOS EM BIOMETEOROLOGIA, 2014).

\section{Sampling and rumen protozoa}

Samples were collected from animals slaughtered at a commercial abattoir, Miolar Alimentos Ltda., located in the municipality of Dois Vizinhos, Southwest of Paraná, State Brazil, after 12 hours of fasting. Samples were obtained from the center of ruminal mass, homogenized, and fixed in an $18.5 \%$ formaldehyde solution (DEHORITY, 1984). Quantification was performed using a Sedgewick-Rafter counting chamber, according to the procedures described by Dehority (1984) and following the modification proposed by D'Agosto and Carneiro (1999). Genus identification was through the method of Ogimoto and Imai (1981).

\section{Bromatological analysis}

Simulations of pasture and gathering of food supplied to the animals were carried out to determine the bromatological composition of the pasture. Samples were dried in forced ventilation greenhouses at $55{ }^{\circ} \mathrm{C}$ for 72 hours, for subsequent bromatological analysis of dry matter (DM), mineral matter (MM), crude protein $(\mathrm{CP})$, ether extract (EE), neutral detergent fiber (NDF), and acid detergent fiber (ADF) according to the method of Silva and Queiroz (2004) (Table 1). 
Table 1. Chemical composition (\% dry matter) of feed supplied to Nellore and Crossbreed European beef cattle using different feeding systems.

\begin{tabular}{ccccccccc}
\hline & Confinement & \multicolumn{3}{c}{ Pasture } & \multicolumn{3}{c}{ Pasture supplement } \\
\hline $\begin{array}{c}\text { Nutrient }{ }^{1} \\
(\% \mathrm{DM})\end{array}$ & Concentrate & $\begin{array}{c}\text { Corn } \\
\text { silage }\end{array}$ & $\begin{array}{c}\text { Ryegrass } \\
\text { (Crossbred) }\end{array}$ & $\begin{array}{c}\text { Bermuda } \\
\text { grass } \\
\text { (Nellore) }\end{array}$ & $\begin{array}{c}\text { Oats }+ \\
\text { Ryegrass } \\
\text { (Crossbred) }\end{array}$ & $\begin{array}{c}\text { Supplement }{ }^{2} \\
\text { (Crossbred) }\end{array}$ & $\begin{array}{c}\text { Bermuda } \\
\text { grass } \\
\text { (Nellore) }\end{array}$ & $\begin{array}{c}\text { Supple- } \\
\text { ment }^{2} \\
(\text { Nellore })\end{array}$ \\
\hline DM & 86.98 & 32.87 & 20.14 & 36.36 & 20.32 & 90.32 & 34.05 & 87.26 \\
CP & 16.06 & 9.86 & 19.33 & 10.05 & 11.68 & 17.31 & 10.65 & 17.61 \\
EE & 1.96 & 3.63 & 2.85 & 2.12 & 2.71 & 2.94 & 2.53 & 1.90 \\
MM & 5.30 & 4.46 & 8.38 & 9.55 & 7.12 & 7.45 & 8.61 & 6.72 \\
NDF & 25.85 & 44.90 & 57.51 & 75.23 & 62.30 & 29.95 & 65.16 & 34.79 \\
ADF & 14.06 & 18.63 & 29.96 & 38.20 & 33.81 & 12.82 & 33.02 & 13.55 \\
\hline
\end{tabular}

${ }^{1} \mathrm{DM}=$ dry matter; $\mathrm{CP}=$ crude protein; $\mathrm{EE}=$ ether extract; $\mathrm{MM}=$ Mineral matter; $\mathrm{NDF}=$ neutral detergent fiber; $\mathrm{ADF}=$ acid detergent fiber

${ }^{2}$ commercial protein and supplement with $18 \%$ crude protein, provided at the amount of $2 \%$ of body weight.

\section{Statistical analysis}

The experimental design was entirely causal in a bi-factorial scheme $(2 \times 3)$, with two genetic groups of beef cattle (Nellore and crossbreed European beef cattle), three feeding systems (pasture, pasture supplement and confined), and with ten repetitions per treatment. The data were analyzed using the general linear model, assuming a Poisson distribution with a logarithm liaison function and a level of significance of $1 \%$ (SAS, 2001), according to the following model:

$$
Y_{i j k}=e^{\eta}+\varepsilon_{i j k}
$$

In which:

$Y_{i j k}$ : is the number of specimens in the animal of $j$ breed submitted to $i$ diet;

$e:$ is the base of the Neperian logarithm;

$\eta$ : is the linear function of the parameters in the formula in which;

$\mu$ : is the intercept;

$d_{i}:$ is the effect of the diet $\mathrm{i} ; \mathrm{i}=1,2$, or 3 ;

$r_{j}:$ is the breed effect $\mathrm{j}=1$ or 2 ;

$d_{r i j}:$ is the effect of the interaction between diet and breed; $\varepsilon_{i j k}:$ is the aleatory error associated with each observation $Y_{i j k}$.

Additionally, the main components of the data were submitted to analysis (SAEG, 2007). The main purpose of this analysis was to reduce or eliminate overlap and identify representative forms of data from linear combinations of the original variables. The first two main components were analyzed by means of minimum squares, assuming the previously defined model:

$Y_{i j k}=\mu+d_{i}+r_{j}+d_{r i j}+O_{i j k}$

In which:

$Y_{i j k}$ : is the number of specimens in the animal of $j$ breed submitted to $i$ diet;

$\mu:$ is the intercept;

$d_{i}:$ is the effect of the diet $\mathrm{i} ; \mathrm{i}=1,2$, or 3 ;

$r_{j}:$ is the breed effect $\mathrm{j}=1$ or 2 ;

$d_{r i j}:$ is the effect of the interaction between diet and breed;

$O_{i j k}:$ is the aleatory error associated with each observation . 


\section{Results}

We identified 14 genera of rumen ciliates belonging to three families (Table 2). The genera Buetschlia, Elytroplastron, Epidinium, Ostracodinium, and Polyplastron showed variations in occurrence and distribution according to the genetic group and/or treatment. The other genera were observed in all treatment and genetic groups. The genus Elytroplastron was observed in four of the 60 animals analyzed $(6.66 \%$ prevalence) and the genus Buetschlia in one animal (prevalence of $1.66 \%$ ). Thus, these genera were not included in the statistical analysis. Ciliates belonging to the order Entodiniomorphida and characterized preferentially as cellulolytic, namely Eodinium, Epidinium, Eremoplastron, Eudiplodinium, Metadinium,
Ostracodinium and Polyplastron were observed at the highest density in animals maintained by pasture $(\mathrm{P}<0.01)$. As there was a significant interaction $(\mathrm{P}<0.01)$ between diets and genetic groups, genera were analyzed through separation based on the genera linear model, assuming a Poisson distribution. The genus Dasytricha showed higher density $(\mathrm{P}<0.01)$ in dietss with pasture supplement $\left(62.71 \times 10^{4}\right.$ protozoa $\left./ \mathrm{ml}\right)$ and pasture $(22.91 \times$ $10^{4}$ protozoa $\left./ \mathrm{ml}\right)$ compared to confined diet $(0.31$ $\times 10^{4}$ protozoa $/ \mathrm{ml}$ ). In addition to this variation between treatments, Dasytricha showed differences based on the genetic group upon analysis of the confined treatment group; densities of $0.54 \times 10^{4}$ and $0.08 \times 10^{4}$ protozoa $/ \mathrm{ml}$ were observed in the Nellore group and the crossbred European beef cattle animals, respectively.

Table 2. Average $\left(\times 10^{4} \mathrm{~mL}^{-1}\right)$ rumen protozoa observed in Nellore and crossbreed European beef catle $(\mathrm{n}=60)$ cattle using different feeding systems.

\begin{tabular}{lcccccc}
\hline Rumen protozoa & \multicolumn{3}{c}{ Crossbreed } & & Nellore \\
\hline Order/Family/Genera & Confined & Pasture & $\begin{array}{c}\text { Pasture } \\
\text { supplement }\end{array}$ & Confined & Pasture & $\begin{array}{c}\text { Pasture } \\
\text { supplement }\end{array}$ \\
\hline Vestibuliferida & & & & & \\
Isotrichidae & & & & & \\
Dasytricha & 0.08 & 24.25 & 11.08 & 0.54 & 21.57 & 1.45 \\
Isotricha & 0.22 & 8.80 & 3.74 & 5.26 & 41.58 & 0.11 \\
Entodiniomosphida & & & & & \\
Buestchliidae & & & & & \\
Buetschlia & & & & & & \\
Ophryoscolecidae & & & & & \\
Entodinium & 33.69 & 68.43 & 52.68 & 233.37 & 130.76 & 24.19 \\
Diplodinium & 2.35 & 5.28 & 1.74 & 9.77 & 5.65 & 0.096 \\
Diplopastron & 0.62 & 2.73 & 1.42 & 4.86 & 4.00 & 0.36 \\
Elytroplastron & 0.016 & & & 0.036 & 0.080 & \\
Eodinium & 0.19 & 1.26 & 0.61 & 0.61 & 1.36 & 0.36 \\
Epidinium & 0.47 & 7.61 & 5.68 & & 6.25 & 0.03 \\
Eremoplastron & 0.39 & 1.93 & 0.54 & 1.19 & 3.10 & \\
Eudiplodinium & 0.49 & 2.44 & 3.07 & 0.67 & 4.03 & 0.14 \\
Metadinium & 0.04 & 1.50 & 1.63 & 1.05 & 2.20 & \\
Ostracodinium & & 2.76 & 4.99 & & 4.43 & 0.03 \\
Polyplastron & & 1.36 & 0.84 & 2.09 & 1.29 & 0.04 \\
\hline
\end{tabular}


In the pasture treatment group, the genus Isotricha had a higher density in the Nellore $\left(41.58 \times 10^{4} / \mathrm{ml}\right)$ group compared to the crossbred European beef cattle group $\left(8.80 \times 10^{4} / \mathrm{ml}\right)(\mathrm{P}<0.01)$. However, for animals in the pasture supplement group, these populations exhibited opposite behavior, with densities of $3.74 \times 10^{4}$ and $0.11 \times 10^{4}$ protozoa / $\mathrm{ml}$ in crossbred European beef cattle and Nellore $(\mathrm{P}<0.01)$ animals, respectively. According to the treatment, there was a higher density of this genus in the animals maintained in pasture $\left(25.19 \times 10^{4} /\right.$ $\mathrm{ml})$, followed by confined animals $\left(2.74 \times 10^{4} / \mathrm{ml}\right)$, and the pasture supplemented group $\left(1.93 \times 10^{4} / \mathrm{ml}\right)$ $(\mathrm{P}<0.01)$.

The genus Entodinium had $100 \%$ prevalence and predominated in all treatment and genetic groups; in the crossbred European beef cattle animals the density was $68.43,52.68$, and 33.69 $\times 10^{4} / \mathrm{ml}$ for treatment groups of pasture, pasture supplement, and confined, respectively. In Nellore animals, this genus showed densities of 130.76, 24.19 , and $233.37 \times 10^{4} / \mathrm{ml}$. On average, between diets for both genetic groups, Entodinium ciliates were observed at the highest density in confined animals $\left(133.53 \times 10^{4} / \mathrm{ml}\right)$. Populations of the genus Diplodinium were similar in both genetic groups for pasture treated animals $\left(5.28 \times 10^{4} / \mathrm{ml}\right.$ and 5.65 x $10^{4} / \mathrm{ml}$ for crossbred European beef cattle and Nellore, respectively) and the pasture supplement group $\left(1.74\right.$ and $0.096 \times 10^{4} / \mathrm{ml}$ for crossbred European beef cattle and Nellore, respectively). However, variations related to genetic group were observed in the confined animal group, wherein Diplodinium density was 9.77 and $2.35 \times 10^{4}$ / for Nellore and crossbreed european beef cattle groups, respectively.

Considering the average counts obtained for each genetic group and for each treatment evaluated, it was observed that the genera Diploplastron, Eodinium, and Epidinium were present at a higher density in animals in the pasture group, and counts were $3.36,1.31$, and $6.93 \times 10^{4}$ protozoa $/ \mathrm{ml}$ of rumen contents, respectively. When considering the influence of breed, the prevalence of Diploplastron showed a similar trend to that of Diplodinium, with higher density in the Nellore group (4.86 x 104/ $\mathrm{ml}$ ) compared to that of the crossbreed european beef cattle group $\left(0.62 \times 10^{4} / \mathrm{ml}\right)$ in the confined treatment condition. A higher prevalence in animals of the pasture group was also observed for the genera Eremoplastron and Eudiplodinium (2.52 and $3.24 \times 10^{4} / \mathrm{ml}$, respectively). According to genetic group, the genus Eremoplastron was identified in the highest proportion in Nellore animals (1.43 $\left.\mathrm{x} 10^{4} / \mathrm{ml}\right)$ compared to crossbred Nellore $\times$ European animals $\left(0.95 \times 10^{4} / \mathrm{ml}\right)$. For the genus Eudiplodinium, the cross bred European beef cattle animals were found to contain higher levels of ciliates compared to that of the Nellore group (2.00 x $10^{4} / \mathrm{ml}$ and $1.61 \times 10^{4} / \mathrm{ml}$, respectively).

To better explain the correlations between characteristics studied, the data were subjected to Principal Component Analysis (PCA). The main purpose of this analysis was to reduce or eliminate overlap and identify representative forms of data from linear combinations of the original variables. Of the 12 variables, the first two components explained $54.99 \%$ of the total variation of all genera. On this basis, the other 10 components were ignored, and the coefficients of the principal components $\mathrm{Y}_{1}$ and $\mathrm{Y}_{2}$ was:

$Y_{1}=0.09295$ Entodinium +0.01392 Dasytricha +0.17296 Isotricha $+0.08420+$ Diplodinium + 0.12819 Diploplastron +0.13488 Epidinium + 0.10995 Metadinium +0.13323 Eremoplastron + 0.17526 Eudiplodinium +0.12407 Polyplastron + 0.15693 Eodinium +0.13441 Ostracodinium

$Y_{2}=0.31657$ Entodinium - 0.13659 Dasytricha +0.00781 Isotricha +0.25252 Diplodinium + 0.21387 Diploplastron - 0.23687 Epidinium 0.9682 Metadinium +0.07536 Eremoplastron 0.14306 Eudiplodinium +0.25221 Polyplastron + 0.03647 Eodinium - 0.26840 Ostracodinium

The genera Dasytricha, Isotricha, Eudiplodinium, and Eodinium were more related to $\mathrm{Y}_{1}$ (Table 3). 
Diet had a significant effect $(\mathrm{P}<0.01)$ for both components, however for $\mathrm{Y}_{1}$, the breed had no significant effect $(P>0.01)$. A significant effect was observed $(\mathrm{P}<0.01)$ for breed interaction $\mathrm{x}$ diet for confined animals and animals in the pasture supplement treatment group. However, when each genetic group among the three diets was analyzed, a significant difference was observed $(\mathrm{P}<0.01)$ for the crossbred European beef cattle animals and for the Nellore group. The genus Entodinium was more related to $\mathrm{Y}_{2}$, whereas Ostracodinium, Epidinium, Eudiplodinium, Dasytricha, and Metadinium showed a negative correlation with $\mathrm{Y}_{2}$. Only animals in the pasture supplementation group had no significant effect $(\mathrm{P}>0.01)$ compared to $\mathrm{Y}_{2}$. For $\mathrm{Y}_{2}$, breed had an effect $(\mathrm{P}<0.01)$, whereas for interaction breed $\mathrm{x}$ diet had an observable effect for Nellore cattle (P $<0.01)$. The genus Polyplastron showed a strong correlation with $\mathrm{Y}_{1}$ and $\mathrm{Y}_{2}$ (Table 3).

Table 3. Correlations of rumen protozoa with main components $\mathrm{Y}_{1}$ and $\mathrm{Y}_{2}$.

\begin{tabular}{lcc}
\hline \multirow{2}{*}{ Genera } & \multicolumn{2}{c}{ Principal Component } \\
\cline { 2 - 3 } & $\mathrm{Y}_{1}$ & $\mathrm{Y}_{2}$ \\
\hline Eodiniumn & 0.41003 & 0.69264 \\
Dasytricha & 0.73540 & -0.29885 \\
Isotricha & 0.76292 & 0.01708 \\
Diplodinium & 0.37141 & 0.55251 \\
Diploplastron & 0.56574 & 0.46795 \\
Epidinium & 0.59496 & -0.51826 \\
Metadinium & 0.48498 & -0.21184 \\
Eremoplastron & 0.58770 & 0.16489 \\
Eudiplodinium & 0.77307 & -0.31300 \\
Polyplastron & 0.54727 & 0.55183 \\
Eodinium & 0.69223 & 0.07979 \\
Ostracodinium & 0.59287 & -0.58724 \\
\hline
\end{tabular}

\section{Discussion}

In this study, the differences in the composition and density of some rumen protozoa populations $(\mathrm{P}<0.01)$ complement previous reports of these parameters in relation to genetic groups. Data herein also expands upon the understanding of these effects, as few studies have addressed this. Variations in the populations of rumen protozoa between host breeds administered the same diet can be very significant, with dramatic changes in the composition and density of species, as reported by Voigt et al. (2000). These differences can also be more subtle, with only a few species found exclusively in any given genotype group (ALIPOUR, 2012). According to O'Kelly and Spiers (1992), the population density of protozoa might vary between cattle breeds; a higher density of these microorganisms contributes to quantitative differences between breeds in regards to the products of digestion. This can lead to achieving and maintaining a higher body weight, as more metabolic energy and essential nutrients are supplied from the rumen to body tissues. Cersosimo et al. (2016) demonstrated that breed and lactation stage alter the rumen protozoa fatty acid profiles and community structures in primiparous dairy cattle maintained with the same diet. In this study, the breed affected the prevalence of two rumen protozoa genera, Entodinium and Metadinium. In the present study, differences in the prevalence of some genera were observed within the same breed 
and treatment condition. The alterations, as well as differences between genetic groups, might be related to factors inherent to the hosts themselves or their metabolism (MARTINELE et al., 2008).

Protozoa belonging of the genera Dasytricha and Isotricha, which were identified at a higher prevalence in animals in the pasture treatment and pasture supplement groups, are commonly found at a higher density in the rumen of grazing animals or those fed diets containing high levels of hay. This is due to their ability to degrade non-structural polysaccharides and soluble carbohydrates of plants (WILLIAMS; COLEMAN, 1992; WRIGH et al., 2015). The high density of Entodiniomorphid protozoa in ruminants fed fresh grass has been noted previously (HUWS et al., 2009). Protozoa density and Entodiniomorphid abundance might be higher for grass-fed steers than for those fed hay, which has implications in the profile of fatty acids that are produced by the protozoa and made available to the ruminants. The polyunsaturated fatty acid (PUFA)rich nature of rumen protozoa is a consequence of ingestion of PUFA-rich chloroplasts, as rumen protozoa from steers fed fresh grass were richer in PUFAs, compared to those from hay-fed steers (HUWS et al., 2009).

Diets rich in forages vary extensively in the availability of nutrients and in the presence of compounds such as cellulose, hemicellulose, and lignin, which influences the microbial activity (WILLIAMS; COLEMAN, 1992; DEHORITY, 2003; WRIGH et al., 2015). Among the genera of ciliates identified, Epidinium is considered to participate in the degradation of plant structural polysaccharides. These protozoa are among the highest in terms of cellulase and hemicellulase production, which contributes to higher degradation of the cell wall of fodder plants (WILLIAM; COLEMAN, 1992). Thus, the high proportion of this genus isolated from the pasture animal group than from the confined group is in accordance with the intense requirement for cellulolytic activity required for these cattle.
Another important factor for studying the protozoa of ruminants reared in pastures in the changes in vegetation characteristics resulting from changes to physiological cycles and seasonal variations. These alterations can result in fluctuations in nutrient and dry matter content, which changes the nutritional value forage species over time (BONHOMME-FLORENTIN, 1974; MANELLA; LOURENÇO, 2004; MARTINELE et al., 2010). Despite differences in pastures utilized in this study, specifically winter grass (Ryegrass) and other summer grass (Bermuda Grass), no differences were observed ciliates communities between the two genetic pasture-fed groups, probably because both grasses used in this study were of satisfactory bromatological quality. Furthermore, fibrous diets stimulate rumination and saliva secretion, which maintains a favorable rumen $\mathrm{pH}$ for the microbiota, and especially for cellulolytic species (DEHORITY, 2003).

The genus Entodinium was observed in all animals, corroborating many studies on rumen ciliates reporting a high prevalence of this genus in domestic ruminants under different feeding conditions (MARTINELE et al., 2010; CEDROLA et al., 2016). According to Martinele et al. (2008), the high prevalence and density of Entodinium may be related to the fact that this genus has a large number of species, many of which are widely distributed, and are characterized by their ability to colonize the rumen environment. Although the genus is biochemically heterogeneous, these protozoa engulf starch and attached amylolytic bacteria, thus regulating the rate of starch fermentation in the rumen (WRIGHT, 2015).

Diet had a significant effect $(\mathrm{P}<0.01)$ for both components; however, for $\mathrm{Y}_{1}$, breed was shown to have no effect $(\mathrm{P}>0.01)$. A significant effect $(\mathrm{P}<0.01)$ was observed for breed interaction $\mathrm{x}$ diet for confined animals and animals in the pasture supplement group. This shows that the factors that should be considered for research or ruminal microbiota are those external to the rumen 
environment (such as diet composition, type of management, frequency, and dietary restrictions, among others) or those inherent to the host (for examples, species and host breed, physiological status, and other characteristics of the host), and that these factors are interrelated. The interdependence of these factors highlights the importance of studies that employ a broader approach to research aspects related to variations in ruminal microbiota, as opposed to most studies that only focus on the effects of diet.

In conclusion, the two cattle breeds studied showed variations in the occurrence, prevalence, and density of rumen protozoa arising from differences between genetic groups and feeding systems (type of diet). In addition, these factors interact to determine the composition, structure, and density of the protozoa community. Besides these factors, it was found that there were individual influences on the occurrence of ciliates; this was especially true for the genus Buetschlia identified in one animal. This is one of the few reports of this genus in ruminants (OGIMOTO; IMAI, 1981; WILLIAMS; COLEMAN, 1992).

\section{Acknowledgements}

The authors wish to thank the Federal Technological University of Paraná and the farms for supplying the animals that were used in the study.

CAPES and FAPEMIG by the grant of the scholarship.

\section{References}

ALIPOUR, D. Ruminal ciliated protozoa in baloochi and sindhi camel breeds. Journal of Veterinary Research, Napoli, v. 67, n. 3, p. 257-263, 2012.

ARTMANN, A. T.; TOMA, S. H.; PINHEIRO, N. J.; ROMERO, J.; CARVALHO, A. M.; MONTEIRO, T. Breeding and cattle $1 / 2$ blood taurino $\times 1 / 2$ blood zebu in Brazil. Revista Científica de Medicina Veterinária, Garça, ano XII, n. 22, p. 1-10, 2014.
BONHOMME-FLORENTIN, A. Contribution à l'lètude de La physiologie dês ciliés entodiniomorphes endocommensaux des ruminats et des équidés. Annales des Sciences Naturelles, London, v. 16, n. 12, p. 155-283, 1974.

CEDROLA, F.; MARTINELE, I.; DIAS, R. J. P.; FREGUliA, P.; D'AGOSTO, M. Rumen ciliates in Brazilian sheep (Ovis aries) and redescription of Entodinium contractum (Entodiniomorphida, Ophryoscolecidae). Zootaxa, New Zealand, v. 4088, n. 2, p. 292-300, 2016.

CERSOSIMO, L. M.; BAINBRIDGE, M. L.; WRIGHT, A. D. G.; KRAFT, J. Breed and lactation stage alter the rumen protozoal fatty acid profiles and community structures in primiparous dairy cattle. Journal of Agricultural and Food Chemistry, Washington, v. 64, n. 9, p. 2021-2029, 2016.

D'AGosto, M.; CARNEIRO, M. E. Evaluation of lugol solution used for counting rúmen ciliates. Revista Brasileira de Zoologia, Curitiba, v. 16, n. 3, p. 725-729, 1999.

DEHORITY, B. A. Evaluation of subsampling and fixation procedures used for counting rumen protozoa. Applied and Environmental Microbiology, Washington, v. 48 , n. 1, p. 182-185, 1984.

DEHORITY, B. A. Protozoa of the digestive tract of herbivorous mammals. Insect Science and its Applications, Cambridge, v. 7, n. 3, p. 279-296, 1986.

DEHORITY, B. A. Rumen microbiology. Nottinghan: Nottinghan University Press, 2003. 380 p.

GEBIOMET - GRUPO DE ESTUDOS EM BIOMETEOROLOGIA. Dois Vizinhos: Universidade Tecnológica Federal do Paraná, 2014. Disponível em: <www.gebiomet.com.br>. Acesso em: 20 jan. 2015.

HUWS, S. A.; KIM, E. J.; KINGSTON-SMITH, A. H.; LEE, M. R. F.; MUETZEL, S. M.; COOKSON, A. R.; NEWBOLD, C. J.; WALLACE, R. J.; SCOLLAN, N. D. Rumen protozoa are rich in polyunsaturated fatty acids due to the ingestion of chloroplasts. FEMS Microbiology Ecology, Bethesda, v. 69, n. 3, p. 461-471, 2009.

MANELlA, M. Q.; LOURENÇO, A. J. População de protozoários ciliados no rúmen de bovinos nelore em pastos de Brachiaria brizantha Marandu recebendo suplemento protéico ou com livre acesso a banco de proteína de Leucaena leucocephala nas diferentes estações do ano. Boletim de Indústria Animal, Nova Odessa, v. 61, n. 1, p. 1-11, 2004.

MARTINELE, I.; SANTOS, G. R. A.; MATOS, D. S.; BATISTA, A. M. V.; D’AGOSTO, M. Diet botanical 
composition and rumen protozoa of sheep in brazilian semi-arid. Archivos de Zootecnia, Cordoba, v. 59, n. 226, p. 169-175, 2010.

MARTINELE, I.; SANTOS, G. R. A.; MATOS, D. S.; BATISTA, A. M. V.; D’AGOSTO, M. Protozoários ciliados no rúmen de ovinos mestiços mantidos em pastagem natural de caatinga. Revista Brasileira de Saúde e Produção Animal, Salvador, v. 9, n. 2, p. 280292, 2008.

NEWBOLD, C. J.; de la FUENTE, G.; BELANCHE, A.; RAMOS-MORALES, E.; MCEWAN, N. R. The role of ciliate protozoa in the rumen. Frontiers in Microbiology, Lausanne, v. 1313, n. 6, p. 1-7, 2015.

OGIMOTO, K.; IMAI, S. Atlas of rumen microbiology. Tokyo: Japan Scientificv Societies, 1981. 268 p.

O'KELLY, J. C.; SPIERS, W. G. Possible contribution of protozoa to diferences in rumen metabolism between cattle breeds. Australian Journal of Agricultural Research, Mailing, v. 43, n. 8, p. 1795-1808, 1992.
SILVA, D. J.; QUEIROZ, A. C. Análises de alimentos: métodos químicos e biológicos. 3. ed. Viçosa, MG: Editora UFV, 2004, 235 p.

SISTEMA PARA ANÁLISES ESTATÍSTICAS - SAEG. Versão 9.1: Fundação Arthur Bernardes - UFV - Viçosa, MG, 2007.

STATISTICAL ANALYSIS SYSTEM - SAS. System for Microsoft Windows: release 8.2. New York: Cary, 2001.

VOIGT, J.; JENTSCH, W.; KUHLA, S.; MATTHES, H. D.; DERNO, M. Rumen fermentation and retention time of the digesta in growing cattle of the breeds BlackWhite Dairy Cattle, Galloway, and Highland. Arch Tierz, Dummerstorf, v. 43, n. 6, p. 606-620, 2000.

WILliAMS, A. G.; COLEMAN, G. S. The rumen protozoa. New York: Springer-Verlag, 1992, 423 p.

WRIGHT, A. D. Rumen protozoa. In: PUNIYA, A. K.; SINGH, R.; KAMRA, D. N. Rumen microbiology: from evolution to revolution. New York: Springer-Verlag, 2015, p. 113-120. 